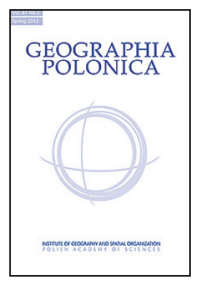 \\ INSTITUTE OF GEOGRAPHY AND SPATIAL ORGANIZATION \\ POLISH ACADEMY OF SCIENCES \\ www.igipz.pan.pl \\ www.geographiapolonica.pl
}

\title{
DIVERSE AND DIFFERENT: ON THE FACES OF SOCIAL SOLIDARITY IN WARSAW
}

\section{Ewa Korcelli-Olejniczak - Filip Piotrowski}

Institute of Geography and Spatial Organization

Polish Academy of Sciences

Twarda 51/55, 00-818 Warsaw: Poland

e-mails: eko@twarda.pan.pl • piotrowskif@twarda.pan.pl

\begin{abstract}
Growing spatial mobility is a challenge to cities in many ways. It brings positive development impulses and social diversity, but at the same time contributes to a decomposition of existing structures and is a challenge to planning. Under the conditions of the obvious signum temporis - an intensifying hyper-diversity and a growing liquidity of values with weakening social bonds and a less evident physical rootedness, the question should be posed whether urban places can still sustain their interactive local identity based on social solidarity, mutual support and trust. The problem is tested on the example of two districts of Warsaw - Praga Północ and Ursynów. In the search for regularities in the relation between the level of social diversity on one side and social solidarity on the other, the analysis focuses on the areas characterised by fundamental differences in their historic development, built environment and social structure.
\end{abstract}

\section{Key words}

social diversity $\bullet$ social solidarity $\bullet$ post-socialist city $・$ Warsaw $・$ Praga Północ $・$ Ursynów

"The cross-links that enable a district to function as a Thing are neither vague nor mysterious. They consist of working relationships among specific people, many of them without much more in common than that they share a fragment of geography"

(Jacobs 1961:54)

\section{Introduction}

In the early 1960s, Webber $(1963,1964)$ announced the birth of a 'non-place urban realm' and of a 'community without propinquity'.
He identified their source in the development of communication technologies and the diminishing role of 'place' as a physical setting. As Sheller and Urry (2006) argue, material changes 'dematerialise' social linkages, while especially in highly developed areas, their spatial patterns tend to be 'desynchronised from historical communities and place'. Giddens (2007) confirms the relevance of such understanding by saying that a community today should not necessarily be identified with a physical neighbourhood. Still, the city 
as an entity and an idea has survived as carrier of spirit and values (Bell \& de Shalit 2011), whereas networks of local relationships and the strength of ties (Granovetter 1973) continue to determine its character and sustainability. Hence, the city of today should be interpreted as both place and connectivity, both territoriality and flows (Buttimer 1969; Castells 1996), where the nature of interaction decides about its social integration, cohesion and economic performance.

In the case of a contemporary city, social diversity, generated by spatial mobility, including that related to the gentrification process (Hamnett 1991; Butler 2003; Watts 2009) brings positive development impulses but at the same time contributes to a decomposition of existing social structures (Tasan-Kok et al. 2014). Diversity presents a challenge to policy and planning understood as 'managing co-existence in shared space' (Healey 1997). In line with some interpretations, it weakens social capital (Putnam 2008), and challenges social solidarity (Goodhart 2004), since the glue of a community are common values.

In the present paper, we look at social solidarity as the degree or type of integration of a community, in terms of the interdependence of its constituent parts. The social diversity - social solidarity interrelations are placed in the context of a large post-socialist city which along with typical contemporary metropolitan characteristics carries a specific heritage of its recent past. This relation is approached using the examples of Praga Północ and Ursynów, two subareas of Poland's capital city that differ in terms of their historic development, built environment and social structure. Both subareas are experiencing an inflow of residents - mainly from other parts of Warsaw, as well as other regions of Poland. The inflow consists predominately of middle-class population, which in the case of Praga Północ introduces more socio-economic diversity than in the case of Ursynów. The aim of the paper is to show which factors may be held responsible for the observed patterns of social solidarity, and whether the study areas markedly differ in this respect. At the same time, we consider which of the factors are to be treated as case-specific and which are of a more general nature.

The paper consists of six sections. The introduction is followed by the conceptual background and a methods section indicating the sources and the way the data was collected and analysed. Section four outlines selected characteristics of the study areas focusing on similarities and differences in social composition of the population. Section five presents results of the analysis pertaining to patterns of social interaction, as well as to factors that are responsible for observed variations in the way mutual support and social solidarity are manifested. General conclusions are discussed in the final section.

\section{Conceptual background}

There are some specific features that mark the contemporary development path of major cities in East-Central Europe. One of the important aspects relates to a growing social diversity propelled by economic forces and metropolization processes. It entails the division lines within the society into the 'winners' and the 'losers' of the systemic change (Wectawowicz 1996). With the onset of the transformation period the large cities in EastCentral Europe have accumulated a substantial part of the national human capital resources and became the main engines of economic growth (Lichtenberger 1994).

The term - 'post-socialist city' refers to various dimensions of its spatial structure, typically to housing characteristics, symbolic components of urban space, ownership relations, socio-spatial differentiation. It relates less frequently to population dynamics, as well as functions performed. The notion is also used in a general sense, i.e. attached to the phase of transformation initiated by political events of 1989-1990, the end of which remains to be defined (Tosics 2005; Węcławowicz 2005b). Sykora and Bouzarovski (2011) claim that whilst in most former socialist countries basic institutional changes have been largely completed, social practices and social structures still retain some features of the previous 
system, or are characteristic for a transition period. Among these features, the underdeveloped relations based on trust and reciprocity should be noted. Tölle (2014) interprets this aspect as responsible for the observed paucity of inter-urban networking, although we claim that it can also be attributed to the microlevel, i.e. inter-personal relations within cities and neighbourhoods as manifested by weak cooperation and social solidarity between individuals and resident groups. This approach is also substantiated by results of Czapiński and Panek (2013), who point to major social capital deficits as observed at the current stage of social change in Poland. Our analyses conducted in two districts of Warsaw directly refer to these issues.

Against the situation of typical large Western cities with their ethnic differentiation, urban diversity in a post-socialist setting is mainly attributed to the increasing intraurban spatial mobility, internal in-migration, suburbanization, as well as to an early-stage gentrification (Sykora 2005; Jakóbczyk-Gryszkiewicz 2015). At the neighbourhood level, social heterogeneity is also a legacy of specific housing allocation policies implemented during the socialist past (Węcławowicz 2005a). Today, parallel processes of diversification and uniformization of social space are observed. In the case of Warsaw, a new face of social segregation stems from dynamics of the realestate market (Mendel 2013), as well as the attracting force of the city's labour and higher education markets, which generates in-migration flows (Grochowski et al. 2013; Komornicki et al. 2013; Central Statistical Office 2015). Their volume is expressed by 250,000 de facto residents without domicile registration in addition to quarter of a million of those who commute on a daily or weekly basis from their home areas (Śleszyński 2012). Although Warsaw still retains its ethnically homogeneous structure, the volume of aliens, mainly among temporary residents, is growing (Piekut 2012; Korcelli-Olejniczak et al. 2017).

Łukasiuk (2007) recalls two main motives that stand behind migration moves to Warsaw. One is related to the search for 'solid modernity' based on traditional foundations, such as stability, family and work career; the other reflects the search for what Bauman (2000) calls 'liquid modernity', i.e. the anonymity, dynamics and diversity that a large city offers. The two patterns also correspond to growing social pluralism based on lifestyles, attitudes and options. Next to the demographic, i.e. age and gender related diversity, there is a specific socio-spatial dichotomy developing: traditional households showing a trend towards suburbanisation and modern urbanites displaying a preference for more central city areas (Jałowiecki 1999). In this respect, Warsaw, like other large post-socialist cities witnesses a 'delayed' phase of the metropolisation process (Korcelli \& Korcelli-Olejniczak 2015). Building upon these preconditions, the results presented in this paper pertain less to ethnic divisions, while focusing on such dimensions of social diversity as cultural capital, age, family background and region of origin that differentiate residents at the neighbourhood level. It is in this context that patterns of social solidarity identified in the study areas are traced.

Whereas some authors provide evidence that a growing social diversity in urban areas does not necessarily lead to a decrease of social capital level (Postmes et al. 2005; Stolle et al. 2008), this positive association is not found as dominating in the scientific discourse. Bulter (2003), Putnam (2007), Watts (2009), for example, point to the prevalence of weak, incomplete or conflicting relations between residents of socially diversified areas. Here, a question arises whether social diversity represents the priming factor that is responsible for social capital deficits, or the latter is an outcome of a multitude of processes attributed to social change. In the present case, the low level of social capital - a cost of post-socialist transformation, may be regarded as an additional, albeit important determinant.

Against the forces that negatively impact upon social solidarity in large urban areas, such as the weakening of social bonds between and within social groups and a less 
distinct local rootedness (Gusfield 1975; Badyina \& Golubchikov 2005), there are also factors identified (Korcelli-Olejniczak et al. 2017) that may contribute to the opposite. These can foster local solidarity and stimulate inter-personal and group cooperation. Here, links to the concept of place with its focus on local identity and place attachment seem evident (Tuan 1977; Crow \& Allen 1994; Corcoran 2002). Tuan (1977) holds that space is perceived as place, once it acquires a certain meaning, when values are attached to it. In modern cities, shaped by networks of functional interactions (Webber 1963; Jałowiecki 2010), the human need for embeddedness and local identity are often looked for. It is assumed in this paper that in the case of some individuals, emotional attachment (Lewicka 2008) which sustains individual identity (Hay 1998) may strengthen the sense of belonging and place connectedness (Dekker 2007).

In the research reported on here, we assume that local identity and place attachment may be treated as factors stimulating local social solidarity, also in areas with a notable share of new and/or temporary residents. A reciprocal relation may be expected between place attachment and the involvement in local activities (Vorkin \& Riese 2001; Brown et al 2004; Korcelli-Olejniczak 2014). Upon accepting and identifying with a place of residence, people more often become involved in local activities. At the same time, engagement in local affairs can make residents more attached to their place of living (Bachrach \& Zautra 1985). The present study reflects upon these issues, while analyzing the relation between the resident's local engagement and social solidarity in the area.

\section{Methods}

The paper is based on results of research carried out in Warsaw in 2013-2015 in the framework of EU 7 FP DIVERCITIES', as well

\footnotetext{
${ }^{1}$ Governing Urban Diversity: Creating Social Cohesion, Social Mobility and Economic Performance in Today's Hyper-diversified Cities. Project's Workpackage 6 included 50 in-depth interviews with inhabitants
}

as on other complementary sources. Within the project semi-structured in-depth interviews with 50 residents of Praga Północ were carried out in the period of October 2014-February 2015. They were based on a standard questionnaire designed within DIVERCITIES project. The respondents were selected using several entry points - via representatives of NGOs and local informal organizations, as well as private contacts. We aimed at a balance between the number of old and new residents, based on local residence status, as well as gender. Among new residents, we also searched for foreigners. Their share in the sample turned out to be 10 per cent.

The same questionnaire was applied to interview 25 residents of Ursynów during February-April 2015, with analogous selection criteria used. Additional materials were derived from earlier studies carried out in Ursynów by the first author. These include interviews with local experts conducted in the framework of an earlier international project ${ }^{2}$. They concerned life quality, development perspectives and local engagement in an area with socialist heritage.

When selecting case study areas, we assumed that they should cover both the innercity and peripheral parts of the city, give evidence of population exchange and contain neighbourhoods of different social status of residents.

\section{The case study areas}

As indicated in section two, Warsaw's sociospatial structure reflects the successive settlement process by groups relatively homogenous in age and social status (Smętkowski 2009). Some areas are traditionally marked by poverty - these have recently become subject to revitalization policies (LPR 2004; ZPR 2015).

of a chosen case study area in each of 14 cities analyzed.

2 New Post-Socialist City: Competitive and Attractive (in short the ReNewTown project) has been implemented through the Central Europe Programme cofinanced by the European Regional Development Fund in the period of 2011-2014. 
The positive image of other areas is related to higher level of human capital and quality of public space (Grochowski et al. 2013). The social structure of individual areas is changing owing to in-migration and residential mobility, including early-stage gentrification of innercity districts. The phase, characteristic for postsocialist cities involves an overrepresentation of artists, students and other members of the so called marginal middle-class among the gentryfiers (Grabkowska 2012; Kovacs et al. 2013). Another phenomenon which contributes to social diversity at the district and neighbourhood level is population aging. Both processes have a considerable impact on social relations, including patterns of local social solidarity.

The analysis focuses on two subareas of Warsaw that, following Musil's (2005) identification of typical features of a socialist city, may serve as representative for the category. Musil claims that the most visible imprint of socialism could be found in two areas: the peripheral districts with their symbolic built environment and spatial layout, and the innercity areas often neglected, that turned into nests of social depravation. Following these assumptions, one of the areas selected for the study is the district of Ursynów, situated in the southern sector of Warsaw, covered mostly by large housing estates from the late 1970s till present time. The other, an inner-city district of Praga Północ, had for long been ignored by city authorities and degenerated in what Musil denotes as 'historic slums' (Musil 2005).

The areas selected are to an extent contrasting cases, while sharing some commonalities. Praga, with a generally lower social status of inhabitants, is also socially more diversified (Węcławowicz 1992, Stępniak et al. 2009). Their basic similarity is in- and out-migration and residential mobility.

Praga Północ, with 67.279 inhabitants (Demographic Yearbook of Poland, 2015) is one of the smallest among the 18 administrative districts of Warsaw. In the period of 2002-2014 its population declined by more than 10 per cent, owing both to net population outflow and natural decrease. Unemployment level and the share of social assistance beneficiaries is the highest of Warsaw's districts (District Ranking, 2013). The area experiences a step-wise gentrification related to the search for relatively inexpensive housing in an inner-city location, as well as property restitution process.

Praga's present-day social diversification results from population exchange - an inflow of new residents into a partly closed off, aging local community with entrenched, pre-war traditions and lifestyles. The area was neglected under state-socialism and only a decade ago gained attention of city authorities. Two placebased urban revitalization projects, as well as infrastructural investments aim at a regeneration of the disadvantaged district. Today's Praga presents a mélange of new public and private investments, a specific 'creativecultural' milieu with bohemian atmosphere against a background of socially deprived environments and a touch of folklore. This mix is considered a pull factor that attracts new residents (Korcelli-Olejniczak et al. 2014). In these circumstances, Praga can be defined as alternative, beyond the typical advantages of downtown districts, but with a potential to attract residents and tourists searching for a natural and climatic city.

Ursynów, with 148,385 inhabitants, (Demographic Yearbook of Poland 2015), is among the largest districts both in terms of area and population number. Since 2002 its total population grew by over 9 per cent. The district was developed as a new housing area in the late 1970s and 1980s. Among housing estates constructed at that time it was considered home of the intelligentsia (Majewski 2010). It was gradually extended southwards, now reaching the Kabaty Forest. The district's public infrastructure and services, as well as the availability of green space, makes the area friendly and intimate despite its large scale (Mazur 2012). Its development was accelerated by transportation investments, mainly the construction of the first metro line. The new housing estates are considered among the most attractive residential locations in Warsaw. The district is diversified in terms of population age composition. A family life cycle is visible, with the northern parts inhabited by older generations, 
and the southern by younger people, including in-migrants and temporary residents. For families with children Ursynów is an advantageous location, it occupies the 7th rank among Warsaw's districts. Conversely, Praga Północ scores the last in this respect (Ranking Dzielnic 2013).

\section{Living in the neighbourhood - sources of local solidarity}

As indicated earlier, we assume that the key dimension of social diversity in the study areas concerns population division based on the length of residence status. In the analysis as carried out, this division was introduced a priori by drawing a line between these residents who have lived in the areas since at least the onset of the systemic transformation, and those that moved in later. This divide is important since the transition period brought a deregulation of former housing allocation rules by introducing market principles, and an increase of population mobility in general. Against this distinction, the predisposition of individual residents to manifest mutual local solidarity is evaluated. The analysis aims to demonstrate the role of this division within the study areas. It also shows differences between the latter.

\section{The 'old' and the 'new residents' in Praga Północ and in Ursynów: who they are}

In Praga Północ, the 'old residents' consist of those who were born there, are off-springs of long-term residents, or have lived in the area for at least 25 years. The term 'new residents' refers to those who have moved in after 1989. As we have found, there are some differences between these groups in terms of socioeconomic and demographic parameters ('new residents' are typically better educated, on the average younger and in a better economic situation), whereas their basic dissimilarity refers to social networks they establish. The 'new residents' tend to form wider and more diverse social relations - 'bridging networks' (Putnam 2000), while in the case of 'old residents', the networks are less diversified but the bonds are stronger. The 'new residents' can be generally described as 'early-stage gentrifiers' - artists, students, young families, although the group is more diversified than the term implies.

A characteristic of Praga Północ is a high share of municipal-owned housing stock - nearly half of the total, and well above Warsaw's average. The resource typically constitutes the habitat of Praga's 'old residents', especially those belonging to disadvantaged groups. 'Old residents' also inhabit flats in building blocks erected in the 1960s and 1970s in the cooperative sector. As part of a broader privatisation policy, these flats have successively been converted into privately owned dwellings. Aside from this, there are also smaller pockets consisting of older, low-rise detached houses, often in possession of the same family for a few generations. The 'new residents' are usually associated either with post-1990 multifamily housing, mainly of developer, less frequently of cooperative status, or with old, at present privatised buildings. Aside from this, some among the 'new residents' live in flats within city-owned buildings or in privately rented flats. Regarding the impact on the attitude to the area of residence and on local social relations, this rather differentiated housing situation, both within and among the two basic groups of residents, can, however, be only assessed when linked with other factors that shape individual and group identities.

Among these, the structure of educational attainment, job opportunities and the related pattern of home to work travelling of Praga's residents should be referred to. Praga Północ is characterized by a high unemployment level (150\% of Warsaw's average), with the highest share of population on welfare benefits in the city. These phenomena pertain in an overwhelming proportion to groups here defined as 'old residents'. Our results indicate that social mobility within this group is generally low. Those who are occupationally active, often work in Praga, earn considerably below the city average, and experience relatively low job security. Interestingly, these traits also concern some of the 'new residents', for example 
artists. Typical for the 'new resident' groups, however, is performing white-collar jobs in Warsaw's main business and office districts.

In the case of Ursynów, the 'old residents' are here defined as people who inhabited the area before 1990, and their off-springs, who as the second generation of 'Ursynovians' carry on certain local traditions and social behaviours. Typically, these are persons with university education, performing cultural-cognitive jobs (teachers, medicine doctors, scientists, actors), occupying flats within housing cooperatives in the northern part of Ursynów. Some have moved on to newer buildings constructed in the vicinity or in the southern parts of the district. The 'old residents' are attached to a traditional model of social relations based on family ties and solidarity among the neighbours.

'New residents' are generally more diverse than the former group. They have moved to Ursynów from other districts of Warsaw, are temporary or permanent in-migrants from other regions of Poland, some from abroad. They are typically young to middle-aged, are childless or have small and teenage children, are well-educated, in relatively good, although differentiated financial situation, sometimes with signs of status decline. Social relations within the category of 'new residents' in Ursynów are more diverse than of the 'old residents', though generally less family and place bound.

The housing contrasts as seen in Praga, are not present in Ursynów, although there are marked differences in technical standards between buildings erected before and after 1990. Housing patterns are relatively transparent, with 'old residents' occupying flats (now often privatised), in buildings belonging to housing cooperatives in the northern, but also southern (newer) part of the district. 'Old residents' of so-called 'Green Ursynów'3 live in old one-family houses, those sometimes remembering the pre-war and early post-war period. Among the 'new residents' the share of those who occupy housing of developer-type

\footnotetext{
3 A subarea in Ursynów primarily consisting of onefamily houses. Its character is rather suburban than typically urban
}

is definitely higher. Their housing profile is also characterised by much higher tendency towards flat renting which typically reflects the temporal nature of resident status. In terms of the educational level, job opportunities, social mobility and travel to work patterns, the differences between 'old' and 'new' resident groups are mostly related to the age structure.

\section{Social relations in the local milieu}

Long-term residents in Praga often feel endangered by external impacts related to the inflow of new residents. They develop strong ties, cultural rather than physical, related to local traditions, a common understanding based on unwritten rules of local solidarity: "don't listen too much, don't ask questions, be nice to everyone" (interview with an 'old' resident). They share a negative attitude to diversity as brought about by the 'new residents', since it endangers their secure world: "(...) these new people, they come here with large money and drive their cars out of their garages. They are different. Their behaviour is questionable" (interview with an 'old resident').

Among 'new residents' some typical attitudes are identified with respect to how people perceive their neighbours and surroundings. They include the engaged, the isolated and the ex-territorials, these corresponding to types also distinguished by other authors in different study areas (Butler 2003, Middleton et al. 2005, Watts 2009, Pinkster et al 2014). The engaged are socially active and involved in the neighbourhood development. They maintain diverse networks of relations. Some of them, as good angels have developed social solidarity with Praga's traditions and its native residents: "Some people have assimilated with old Praga. We have a neighbor who fights for the rights of tenants. He represents first the old Praguans who have lived in these buildings since the war, and now these people are at risk of forced eviction" (interview with an 'old resident' of Praga). The insecurity the isolated experience in their neighbourhood is not primarily related to short residence period or their housing or job situation, but 
mostly to the scarcity of friends and relatives, or to unstable financial situation. The isolated sense a lack of physical rootedness, belonging or understanding of local principles and rules: "Now that I think about it, this is not my secure environment, where I feel comfortable" (interview with a 'new resident' of Praga).

The ex-territorials fail to care about their neighbourhood and perform their lives outside its borders. Their social networks rarely include any neighbours, they lead their life within the walls of their flats and cars, work elsewhere and drive their children to school to other districts. For them 'sharing' the area with 'old residents' is rather a problem. They consider Praga Północ to be stigmatized, associated with inherited poverty, deprivation and low life quality. In many cases, the ex-territorials emphasize the temporary character of their residence in the area: "As soon as it is possible, we desire to move out. We have nothing in common with this place" (interview with a 'new' resident of Praga).

In Ursynów, other attitudes prevail. Here, the isolated are not identified as an important group, while the extra-territorials, as people representing a mobile life-style, de-rooted and not place-bound, take the place of ex-territorials. The only approach which corresponds with those identified in Praga Północ are the engaged. Albeit, unlike in Praga, their concerns focus on the accomplishment of group interests; they often lack broader social motivations.

\section{Functional relations and the use of space}

The observation of social relations within and between the 'old' and the 'new residents' shows that the phenomenon of social solidarity can be traced back to two main sources. One of these are functional relations that inter-connect people, concerned with their daily chores and their specific interests, and the way the residents practice these activities in their spatial surroundings. In line with this principle, in Praga activities related to child raising, retirement or pet care are those that bring the relevant people together. Via such activities, a certain local solidarity as type of community integration, develops between people, who next to sharing a piece of geography begin to have more in common (compare: Smith 2005; Wood et al. 2007; Peters et al. 2010; Ouředníček et al. 2012).

Parents actively use public space in their surroundings and encounter other parents in parks, nursery schools and playgrounds, places treated as 'desegregated' areas. Children-related activities usually bring different people together, with evidence of mutual support and solidarity within and between the groups of 'old' and 'new residents'. Interestingly, the interaction and mutual support concerns parents of small children. Issues related to school choice often generate divisions into those who are 'condemned' to send their child to a local, i.e. believed to be a worse school, and others, who decide to drive their off-spring to an educational institution elsewhere.

Signs of local solidarity are also evidenced among older people, who devote their time to activities in their immediate surroundings, use public space to encounter other people, while developing a feeling of belonging, in some cases even local identity: "We have moved in here just recently, but are fascinated by the history and traditions of this area and its people. We kind of became part of it" (interview with a 'new resident' of Praga). Deriving from the interviews with some 'old residents', such people are usually helpful towards their neighbours, and trusted by other residents: "She is not from here, but I can always leave my keys with her" (interview with an 'old resident').

A specific local solidarity is said to be observed between dog-owners. For some people, the duty and life-style becomes a way of meeting people and sharing values, even a source of trust: "I did not know whom to ask, so I asked the lady I meet with the dog every day. I believed she would help me. Whom should I trust, if not another dog-owner..." (interview with a 'new resident'). The least local engagement, as observed for example between students, who usually live in rented flats and spend time outside the place of residence can easily be interpreted as a lack 
of local solidarity. There is, however, no evidence found for the direct inter-linking of such ex-territoriality and low social solidarity level.

Among the residents of Ursynów, both 'old' and 'new', the activity which generates a feeling of social solidarity is related to children, primarily to school children. Unlike in Praga, apart from after-school activities and time spent on playgrounds and parks, parents are mainly concerned with local schools, being very much engaged in educational performance of the institutions. Mutual support and solidarity between parents is very distinct: "our life and social relations focus on children and their life and social relations at school and after school. We constitute a separate family - we, the parents" (interview with a 'new resident' of Ursynów). Another group to be identified as helpful and engaged via local activities are elderly people. These among both 'new' and 'old residents' are often involved in local initiatives, use public space and its facilities to meet and share interests. Especially the long-term residents among this group are helpful and can be trusted: "I think that those older people who have lived here for many years are to be trusted, because they care about the area which they treat as their home" (interview with a 'new resident' of Ursynów).

\section{Emotional relation toward the place of residence}

As evidenced by the interviews in Praga and Ursynów, the second source that the phenomenon of social solidarity can be traced back to, is local identity. We observed that people who show a certain emotional relation toward their surroundings, or have developed a specific local identity tend to be more helpful and to recognize their neighbours' needs - a certain level of integration develops. In Praga, a group which can be described as emotionally attached to the area are local wanderers, people who like to move around their neighbourhood and experience it with all senses: "I moved to this place just recently, and I must say that I am fascinated by its climate, tradition, history. I think that I am starting to belong to this place, just as it starts to belong to me" (interview with a 'new resident'). The same person says: "I already had a chance to support my neighbours. An old lady was ill and her daughter was not there to help. I went to buy groceries. Neighbours should help each other". A French architect who restored an old building to arrange his apartment and studio there, claims that Praga is more natural than other areas in Warsaw and that his interest in it and its people grows with the time he spends there: "with time I started feeling responsible for the surroundings. Not only my house, but the neighbouring houses, the people that live there and need support".

Local wanderers are usually middle-aged and older people. Although we have identified more of such attitude among 'new residents', there are also persons with longer residence history, who declare to: "move around a lot, look at everything, how it used to be and how it changes". The person says: "we help each other when help is needed. It belongs to being here that you help". Another Praga-specific group who develop a local identity and place attachment are loiterers, people usually with only vocational education, often unemployed or retired. Their surroundings are their courtyard, gate and doorstep. Although, in many terms, a pathological category, loiterers usually have an emotional attitude toward their local area and develop a specific local social solidarity with their neighbours: "I bet you can count on most of these guys when in need. They are a part of this place and would not let anybody down" (interview with a 'new resident').

What is typically related to as local identity in Praga, cannot be directly translated into social approaches present in Ursynów. There, emotional engagement is associated with the appreciation of the districts' assets: its green areas and infrastructure, its sports' facilities and friendly social relations: "I have always loved to live here, the place has real qualities" (interview with an 'old resident'). At the same time, some people stress that Ursynów is changing with the inflow of new, often temporary residents. The same interviewee says: "We used to maintain very close relations with 
our neighbours, spent time together and supported each other. Now I hardly know the new people who moved to the area. I don't know if I can trust them, and if I can count on them".

In both study areas, direct and emotional interest is expressed by local activists. In general, this movement originated in the early 1990s and is related to the development of civil society in post-socialist cities. While, in Ursynów, the locally active are both 'old' and 'new' inhabitants in all age groups, in the case of Praga these are commonly well-educated 'new residents'. On top of the growing social awareness observed after 1989, active involvement in Praga Północ is clearly related to the gentrification process in the district. A special group among local activists are artists who often play the role of local integrators.

Local activists in Praga and Ursynów follow different objectives. In the former case, they are engaged in providing support to needy groups, fighting exclusion and organizing forms of social encounter. In the much less socially segregated Ursynów, their function is rather related to a confrontation with dysfunctional institutional regulations, as well as fighting for the rights of various resident groups, for example bikers, pedestrians or school children. What the locally involved have in common, is their local identity which often leads to acts of social solidarity: "I am not interested in politics, but the deeds of my community, the area where I live in. Let me call it local patriotism, or simply local solidarity" (interview with a 'new resident' of Praga Północ).

\section{What shapes social solidarity - how different are the case study areas}

We aim to look at the patterns of social solidarity in the study areas as an outcome of various factors, including social diversity related to the length of residence, but also a multitude of processes attributed to social change and post-socialist transformation.

When confronting the different statements about the low level of mutual trust in Praga Północ, the obstacles mentioned most frequently are: not having common experience related to a past together, being in a different family situation, sharing no interests or values. Interviewees often declare that trust between people from different backgrounds can be built upon two fundaments: a long-time relation or common obligations and goals: "I've known her all my life. I meet her frequently. We don't have much in common, but I trust her" (interview with an 'old resident'); "Well, maybe the reason to trust her is that our children like each other and play together" (interview with a "new resident'). The research conducted shows that parents tend to trust other parents, dog owners trust other dog owners in the neighborhood, 'new residents', despite creating bridging networks usually trust other 'new residents' with a similar socio-economic status.

There are also specific factors that shape solidarity among the 'old residents' of Praga. This trust derives from a local identity which developed after the war, was inherited by next generations and 'fossilized' in the socialist period. A local activist says:

"Among the autochthonic residents of Praga there are people who have known each other all their lives, went to school together, sometimes even broke the law together. The solidarity there is stronger. The newer residents limit their existence and trust to the nearest surroundings, sometimes even their flat. The door is a barrier that isolates them from the world. This concerns the affluent residents to a greater extent". Social solidarity is also related to the willingness to help others. Such solidarity is not only expressed by local activists, whose involvement takes some organizational form ${ }^{4}$, but individual persons as well. The notion of 'good angels' is recalled in a few statements, concerning people who help others on a regular basis, without a special reason. This refers to elderly people much more often

\footnotetext{
4 In an interview with one of the leaders of the Praga Resident's Association 'Michałów', the local activist focuses on the tradition of social solidarity in the area, deriving from the times of the philanthropist Prince Michat Piotr Radziwiłt. He and his wife Maria were known for their engagement in supporting the local poor and building the area's genius loci.
} 
than to younger residents: "There are people I call good angels in our building. Elderly folks, they help everybody. They water flowers, people give them keys to their flats. Everybody trusts them" (interview with a 'new resident'). Such behavior, however, should not be interpreted as universal: "These flats are sold, residents change, new tenants come, they don't integrate. They are not helpful at all" (interview with an 'old resident').

As evidenced by respondents in Ursynów, the main obstacles to mutual trust and solidarity are: the sense of temporality and constant change (people know that they will move due to their job situation), as well as the lack of common interests and goals. The first factor is usually pointed to by 'old residents' when talking about their new neighbours. Many 'new residents' either move from flat to flat or resist to develop social relations in the neighbourhood. A 63-year old man says: "you can't even get used to anyone here, because they are gone by the time you do so. This is a true post-city. It does not remind me of Ursynów in the 1980s when everybody knew their neighbours". Both the temporality and the differences in needs and lifestyles is pointed to by many interviewees who recall the lively and emotional social relations between neighbours in the past: "When my children were small, we were leading a social life here. I keep contact with these people I once knew. But the new residents are usually temporary" (interview with an 'old resident' of Ursynów).

Another obstacle to local solidarity in Ursynów refers to common goals. As 'new residents' are mostly function- and goal-oriented, once the common ground is absent, they fail to develop any reciprocity: "Would I help? I don't know. I don't even know the person. We have nothing in common" (interview with a 'new resident'). On the contrary, when a common goal emerges, it may constitute a basis for an understanding, and they might integrate people. A young business consultant and a tennis enthusiast states:

"My tennis club here around the corner is my second home, or rather, my first home. I have come to know so many people there. We are like a community now. Not only playing tennis but celebrating together. Yes, I can even say I have friends there. I trust them and think, they would help me if I needed help. Those are very diverse people, but usually well-off, well-educated and very ambitious".

While 'old residents' tend to develop a group solidarity, based on more integrated networks within their immediate social environment - relations between neighbours, friends and stronger identification with the place of residence - the 'new residents' claim to develop solidarity with individual persons from their surroundings. In the case of the latter group, such is again related to common interests and recreational and sports activities, club memberships, or a similar professional background. 'Old residents' usually develop relations referring to mutual support concerning daily activities, the organization of family celebrations etc.

To sum up, in Praga, to some extent also in Ursynów, local solidarity derives from traditional local bonds, as in the case of 'old residents'. It is expressed mainly by passive trust or simple acts of support toward neighbours in need. In Ursynów, it more typically unveils with the pursuit of common goals. While smallscale solidarity is reflected by mutual support within functional links between residents, at the larger scale it concerns local projects or the contestation of institutional regulations. It should be emphasized that both in Praga and Ursynów, such solidarity by-passes the criterion of the length of residence, although its basic condition is the development of a local identity.

\section{Conclusions}

In this paper signs of local solidarity, as manifested by trust and mutual support, are traced in two city districts displaying different patterns of social diversity. The areas in question, characterized by specific, yet different imprints of socialism (Musil 2005) experience population change with its prime mover being the early-stage gentrification in one case, and the 
labour market demand driven inflow of permanent and temporary migrants on the other. Hence, in Praga the main dimension of social diversification is the socio-economic component, while in Ursynów it is reflected by intergenerational divides and lifestyle specificity.

There are several issues pointed out in our analysis. Firstly, it is shown that the length of residence plays a certain role as far as the intensity and depth of neighbourhood relations is concerned. An intensity of local social relations prescribed to 'old residents', should rather be interpreted as a 'generational' aspect, attributed to age, cultural background, family traditions, as well as to lower spatial mobility and limited consumerism that prevailed before 1989. In the case of Ursynów, also social homogeneity was of certain importance in this respect. Local solidarity, when expressed by 'old residents' can be perceived as a natural component of bonding capital in the sense of Putnam (2000). In Praga Północ, however, it often assumes the form of group loyalty vis-à-vis any outsider (compare: Elias \& Scotson 1994), whereas in Ursynów it more typically stems from the appreciation of being part of the local, though open milieu.

A distinct type of local solidarity found in Praga can be interpreted as part of a defense strategy against the undergoing social and economic change (Berger \& Luckmann 1966). It can be directly interpreted as a reaction to challenges brought about by the gentrification process. Although expression of local solidarity by 'new residents' is not a rare phenomenon, still, the activity of informal groups they form, or the NGOs fails to be sufficiently strong to build solidarity between the 'old residents' and the newcomers. In this respect, the special role of artists as 'local integrators' is considered as a positive aspect of gentrification (Ley 2003).

Secondly, local solidarity in both Praga and Ursynów, can be directly or indirectly encountered when people are inter-linked by functional relations, common goals or develop a specific local identity. A common goal builds bridging networks between people with different backgrounds. Local identity may lead to local solidarity - the specific type and degree of community integration. In both areas, examples of functional links which can evolve into local solidarity, include child care focussed relations, or those among retirees. Parallel to this, as observed mainly in Praga, the emergence of a specific local identity creates space for local solidarity. In Ursynów, its source is typically the pursuit of common goals related to the district's issues, such as access to green open space or the provision of bike lanes. The involvement of local activists reflects in both cases the blending of goal-oriented actions with the unfolding local identity.

The length of residence factor which shapes the patterns of social relations in the two districts is interpreted both in its nominal and relative terms. On the one hand, time per se is conducive to the formation of social networks and social solidarity; on the other, the systemic change of 1989 has brought about an awakening of civil society, but also a growing spatial mobility and new consumer habits - a challenge to social solidarity. In this context, the solidarity deficits observed can be interpreted as related to variations in age, lifestyles, values and attitudes, that stem from diverging backgrounds, including place of origin, level of education of parents. Still, they also represent an echo of functioning under diverging socio-economic systems. In this sense, the length of residence as a determinant of social solidarity is linked both with a general social change and the socialist heritage of areas under investigation. These factors concern Praga and Ursynów alike, despite all differences in social solidarity patterns.

Finally, the question arises whether the patterns and trends related to the social solidarity - social diversity relation, observed in two areas differently marked by socialist planning, by transition and current social processes, are place-specific or rather comparable to those present in other city areas. It seems that as differentiated a large city space can be, these phenomena are of a more general rather than specific to a post-socialist city character. When understood as a certain type of community integration which includes 
the interdependence of resident groups, local social solidarity is globally challenged by the growing liquidity of values within spaces that experience a constant exchange of residents. There, the sustainability of community bonds is determined by social interest related to what can be synthesized as life quality. In the name of the latter, the residents seek connection to co-residents and to the space in which they live.

\section{References}

BaChrach K.M., Zautra A.J., 1985. Coping with a community stressor: The threat of a hazardous waste facility. Journal of Health and Social Behavior, vol. 26, no. 2, pp. 127-141.

Badyina A., GolubChiKov O., 2005. Gentrification in central Moscow: A market process or a deliberate policy? Money, power and people in housing regeneration in Ostozhenka. Geografiska Annaler. Series B. Human Geography, vol. 87, no. 2, pp. 113-129.

Bauman Z., 2000. Liquid modernity. Malden: Polity Press.

Bell D.A., de Shalit A., 2011. The spirit of cities: Why the identity of a city matters in a global age. Princeton, NJ: Princeton University Press

Berger P.L., Luckmann T., 1966. The social construction of reality: A treatise in the sociology of knowledge. Garden City, NY: Anchor Books.

Brown B., Perkins D.D., Brown G., 2004. Incivilities, place attachment and crime: Block and individual effects. Journal of Environmental Psychology, vol. 24, no. 3, pp. 359-371.

BUtLer T., 2003. Living in the bubble: Gentrification and its 'others' in North London. Urban Studies, vol. 40, no. 12, pp. 2469-2486.

BUtTIMER A. 1969. Social space in interdisciplinary perspective. Geographical Review, vol. 59, no. 3, pp. 417-26.

CASTELLS M., 1996. The rise of the network society: The information age: Economy, society, and culture. Vol. 1, Oxford: Wiley Blackwell.

Central Statistical Office, 2015. Area and population in the territorial profile. Warsaw: Central Statistical Office.

\section{Acknowledgments}

This work is based on research conducted within the project Divercities - Governing Urban Diversity: Creating Social Cohesion, Social Mobility and Economic Performance in Today's Hyper-diversified Cities. This project is funded by the European Union under the 7th Framework Programme; Theme: SSH.2012.2.2.2-1; Governance of cohesion and diversity in urban contexts.

Corcoran M., 2002. Place attachment and community sentiment: A European case study. Canadian Journal of Urban Research, vol. 11, no. 1, pp. 47-67.

Crow G., Allan G., 1994. Community life: Introduction to local social relationships. London: Routledge.

CZAPIŃSKI J., PANEK T., 2015. Social diagnosis: Objective and subjective life quality in Poland. Contemporary Economics, vol. 9, no. 14, Warszawa: Rada Monitoringu Społecznego

DEKKER K., 2007. Social capital, neighbourhood attachment and participation in distressed urban areas: A case study in Utrecht and The Hague. Housing Studies, vol. 22, no. 3, pp. 255-379.

Demographic Yearbook of Poland, 2015. Warsaw: Central Statistical Office.

District Ranking, 2013. Ranking dzielnic Warszawy pod względem atrakcyjności warunków życia. Urząd Statystyczny w Warszawie, Warszawa: Mazowiecki Ośrodek Badań Regionalnych.

Elias N., SCOTSON J.L., 1994. The established and the outsiders: A sociological inquiry into community problems. London: Sage.

GIDDEns A., 2007. Debating diversity. The Guardian, Tuesday 30 October 2007.

Goodhart D., 2004. Too diverse?. London: Prospect Magazine, https://www.prospectmagazine. co.uk/magazine/too-diverse-david-goodhart-multiculturalism-britain-immigration-globalisation [10 June 2017].

GrabKowSKA M., 2012. Regeneration of the postsocialist inner city: Social change and bottom-up transformation in Gdańsk. Gdańsk: Pracownia. 
Granovetter M.S., 1973. The strength of weak ties. American Journal of Sociology, vol. 78, no. 6, pp. 1360-1380.

Grochowski M., Górczyńska M., Stepniak M., Korcelli-Olejniczak E., WęcŁawowicz G., ŚleszrŃski P., Rosik P.,ŚWIĄTEK D., 2013. BEST METROPOLISES - Best development conditions in European metropolises: Paris, Berlin and Warsaw. ESPON Final Report/Version 29/01/2013.

Gusfield J.R., 1975. Community: A critical response. New York-London: Harper \& Row.

HAMnET C. 1991. The blind men and the elephant: The explanation of gentrification. Transactions of the Institute of British Geographers, vol. 16, no. 2, pp. 173-189.

HaY R., 1998. Sense of place in a developmental context. Journal of Environmental Psychology, vol. 18, no. 1, pp. 5-29.

Healey P., 1997. Collaborative planning. London: Macmillan.

JACOBS J., 1961. The Death and life of great American cities. New York: Random House.

JaKÓBCZYK-GrysZKIEWICZ J. (ed.), 2015. Procesy gentryfikacji w obszarach śródmiejskich wielkich miast. Na przykładzie Warszawy, Łodzi i Gdańska. Studia KPZK, vol. 165, Warszawa: Komitet Przestrzennego Zagospodarowania PAN.

JAŁOWIECKI B., 1999. Metropolie. Białystok: Wydawnictwo Wyższej Szkoły Finansów i Zarządzania.

JAŁOWIECKI B., 2010. Społeczne wytwarzanie przestrzeni. Warszawa: Wydawnictwo Naukowe Scholar.

Komornicki T., Korcelli P., SıŁKA P., Śleszrński P., ŚWIĄTEK D., 2013. Powiqzania funkcjonalne między polskim metropoliami. Warszawa: Wydawnictwo Akademickie Sedno, Instytut Geografii i Przestrzennego Zagospodarowania PAN.

Korcelli-Olejniczak E., 2014. Partycypacja nauki i jej instytucji w kształtowaniu przestrzeni miasta [in:] T. Markowski, D. Stawasz D. (eds.), Partnerstwo i odpowiedzialność w funkcjonowaniu miasta, Studia KPZK, vol. 157, Warszawa: Komitet Przestrzennego Zagospodarowania Kraju PAN, pp. 52-63.

Korcelli-Olejniczak E., Bierzyński A., DworzańSKI P., Grochowski M., PIOtrowski F., WęcŁaWoWICZ G., 2017. DIVERCITIES: Dealing with Urban Diversity. The case of Warsaw. Warsaw: IGSO PASc.
Korcelli P., Korcelli-Olejniczak E., 2015. On European metropolisation scenarios and the future course of metropolitan development in Poland. Geographia Polonica, vol. 88, no. 1, pp. 107-121.

Kovacs Z., Wiesner R., Zischner R., 2013. Urban renewal in the inner-city of Budapest: Gentrification from a post-socialist perspective. Urban Studies, vol. 50, vol. pp. 22-38.

LEWICKA M., 2008. Place attachment place identity and place memory: Restoring the forgotten city past. Journal of Environmental Psychology, vol. 28, no. 3, pp. 208-231.

LEY D., 2003. Artists, aestheticisation and the field of gentrification. Urban Studies, vol. 40, no. 12, pp. 2527-2544.

LiCHTENBERger E., 1994. Das metropolitane Zeitalter in Europa in West und Ost. Mitteilungen der Österreichischen Geographischen Gesellschaft, vol. 136, pp. 8-36.

LPR, 2004. Lokalny Program Rewitalizacji Miasta Stołecznego Warszawy na lata 2005-2013. Warszawa: Urząd M.st. Warszawy.

ŁUKASIUK M., 2007. Obcy w mieście: Migracja do wspótczesnej Warszawy. Warszawa: Wydawnictwo Akademickie Żak.

Majewski J.S., 2010. Spacerownik. Warszawa śladami PRL-u. Biblioteka Gazety Wyborczej, Warszawa: Agora SA.

Mazur M., 2012. Witajcie na Ursynowie. Warszawa: Wydawnictwo Myśliński.

Mendel M., 2013. Residential developers as actors of urban transformation in post-socialist Warsaw. Warszawa: Instytut Geografii i Przestrzennego Zagospodarowania PAN [PhD thesis; unpublished manuscript].

Middieton A., Murie A., Growes R., 2005. Social capital and neighbourhoods that work. Urban Studies, vol. 42, no. 10, pp. 1711-1738.

Musil J., 2005. City development in Central and Eastern Europe before 1990: Historical context and socialist legacies [in:] F.E.I Hamilton, K.D. Andrews, N. Pichler-Milanović(eds.), Transformation of cities in Central and Eastern Europe: Towards globalization, Tokyo-New York: United Nations University Press, pp. 22-43.

OuŘední̌̌eK M., Pospí̌́lLová L., ŠPaČKová P.,TemeLOVÁ J., Novák J., 2012. Prostorová typologie a zonace Prahy [in:] M. Ouředníček, Temelová J. (eds.), Sociální proměny pražských čtvrtí, Praha: Academia, pp. 268-297. 
Peters K., Elands B., Buiss A., 2010. Social interactions in urban parks: Stimulating social cohesion?. Urban Forestry \& Urban Greening, vol. 9, no. 2, pp. 93-100.

PIeKUt A., 2012. Visible and invisible ethnic 'Others' in Warsaw: Spaces of encounter and places of exclusion [in:] M. Grubbauer, J. Kusiak (eds.), Chasing Warsaw socio-material dynamics of urban change since 1990. Frankfurt-New York: Campus, pp. 189-212.

Pinkster F.M., Permentier M., Wittebrood K., 2014. Moving considerations of middle-class residents in Dutch disadvantaged neighbourhoods: Exploring the relationship between disorder and attachment. Environment and Planning, vol. 46, no. 12, pp. 2898-2914.

Postmes T., Haslam A., SwaAb R.I., 2005. Social influence in small groups: An interactive model of social identity formation. European Review of Social Psychology, vol. 16, no. 1, pp. 1-42.

Putnam R.D., 2000. Bowling alone: Collapse and revival of American community. New York: Simon \& Schuster.

Putnam R.D. 2007. E Pluribus Unum: Diversity and community in the twenty-first century the 2006 Johan Skytte Prize Lecture. Scandinavian Political Studies, vol. 30, no. 2, pp 137-174.

Putnam R.D., 2008. The rebirth of American civic life. Boston Globe, http://archive.boston.com/ news/nation/articles/2008/03/02/the_rebirth_of_american_civic_life/http://www.bostonglobe.com/ [2 June 2017].

Sheller M., URRY J., 2006. The new mobilities paradigm. Environment and Planning A, vol. 38, no. 2, pp. 207-26.

SMETKOWSKI, M., 2009. Zróżnicowania społeczno-przestrzenne Warszawy - inercja czy metamorfoza struktury miasta?. Przegląd Geograficzny, vol. 81, no. 4, pp. 461-482.

ŚleszYŃSKI P., 2012. Warszawa i Obszar Metropolitalny Warszawy a rozwój Mazowsza, Trendy Rozwojowe Mazowsza, vol. 8, Warszawa: Mazowieckie Biuro Planowania Regionalnego.

SMITH D.P., 2005. 'Studentification': the gentrification factory? [in:] W.R. Atkinson, G. Bridge (eds.), Gentrification in a global context. The new urban colonialism, London: Routledge, pp. 72-89.

Stępniak M., Węctawowicz G., Górczrńska M., BierzYŃski A., 2009. Warszawa w świetle Narodowego Spisu Powszechnego 2002. Atlas
Warszawy, vol. 11, Warszawa: Instytut Geografii i Przestrzennego Zagospodarowania PAN.

Stolle D., Soroko S., Johnston R., 2008. When does diversity erode trust? Neighborhood diversity, interpersonal trust and the mediating effect of social interactions. Political Studies, vol. 56, no. 1, pp. 57-75.

SYKORA L., 2005. Gentrification in post-communist cities [in:] R. Atkinson, G. Bridge (eds.), Gentrification in a global context: The new urban colonialism, New York-London: Routledge, pp. 90-105.

SYKORA L., BouZAROVSKI S., 2011. Multiple transformations: Conceptualising the post-communist urban transition. Urban Studies, vol. 49, no. 1, pp. 43-60.

Tasan-Kok T., van Kempen R., Raco M., Bolt G., 2014. Towards hyper-diversified European cities. A critical literature review. Utrecht: Utrecht University.

Tosics I., 2005. City development in Central and Eastern Europe since 1990: the impacts of internal forces [in:] , F.E.l Hamilton, K.D. Andrews, N. Pichler-Milanović (eds.) Transformation of cities in Central and Eastern Europe: Towards globalization, Tokyo-New York: United Nations University Press, pp. 22-43.

Tölle A., 2014. Transnationalisation of urban development strategies: Peculiarities of the East-Central European post-socialist city [in:] L. Mierzejewska, J. Parysek (eds.), Cities in a complex world: Problems, challenges and prospects, Poznań: Bogucki Wydawnictwo Naukowe, pp. 105-118.

TUAN Y.F., 1977. Space and space: The perspective of experience. Minneapolis: University of Minnesota Press.

WatTS P., 2009. Living in an oasis: Middle-class disaffiliation and selective belonging in an English suburb. Environment and Planning A, vol. 41, no. 12 , pp. 2874-2892.

Webber M.W., 1964. The urban place and the nonplace urban realm [in:] M.W. Webber, Explorations into urban structure, Philadelphia, Pa.: University of Pennsylvania Press.

Webber M.W., 1963. Order in diversity: Community without propinquity [in:] Wingo Lowdon Jr. (ed.) Cities and space: The future use of urban land, Baltimore: The Johns Hopkins Press, pp. 23-56.

WęCŁAWOWICZ G., 1992. Segregacja ludności według poziomu wykształcenia w największych miastach [in:] K. Wódz, K. Czekaj. (eds), 
Szkoła chicagowska w socjologii: Tradycja myśli społecznej i wymogi współczesnej socjologii empirycznej: Materiały pokonferencyjne, Katowice-Warszawa: Uniwersytet Śląski, Polskie Towarzystwo Socjologiczne. Sekcja Socjologii Miasta, pp. 185-222.

WęCŁAWOWICZ G., 1996. Contemporary Poland: Space and Society. London: UCL Press.

Węctawowicz G., 2005a. Poland [in:] R. Kempen, M. Vermeulen, A. Baan (eds.), Urban issues and urban policies in the new EU countries, Burlington: Ashgate, pp. 61-77.

WęcŁawowicz G., 2005b. The Warsaw Metropolitan Area on the eve of Poland's integration into the European Union [in:] I. Hamilton, K. Dimitrovska-Andrews, N. Pilchler-Milanovic. (eds.). Transformation of cities in Central and Eastern Europe: Toward globalization, TokyoNew York-Paris: United Nations University Press, pp. 223-247.

Wood L.J., Giles-Corti B., Bulsara M.K., Bosch D.A., 2007. More than a furry companion: The ripple effect of companion animals on neighbourhood interactions and sense of community. Society \& Animals, vol. 15, no. 1, pp. 43-56.

VORKIN M., RIESE H., 2001. Environmental concern in a local context: The significance of place at tachment. Environment \& Behavior, vol. 33, no. 2, pp. 249-263.

ZPR, 2015. Zintegrowany Program Rewitalizacji Miasta St. Warszawy. Warszawa: Urzad M.st. Warszawy. 